\title{
Measurement of Natural Radioactivity in Lagoon Sands Used in Construction in the District of Abidjan, Côte d'Ivoire
}

\author{
Olkalé Jean-Claude Brigui ${ }^{*}$, Tekpo Paul Amewe Dali' ${ }^{1}$, Koudou Djagouri², \\ Bogbé Douo Louis Huberson Gogon ${ }^{1,3}$, Samafou Penabei ${ }^{4}$, \\ Aka Antonin Koua ${ }^{1,3}$, Georges Alain Monnehan ${ }^{1,3}$ \\ ${ }^{1}$ Laboratory of Material Sciences, Environment and Solar Energy (LASMES), Université Félix Houphouët-Boigny, Abidjan, Côte \\ d'Ivoire \\ ${ }^{2}$ Higher Teacher Training College (ENS), Abidjan, Côte d'Ivoire \\ ${ }^{3}$ Nuclear Radiation Protection, Safety and Security Authority (ARSN), Abidjan, Côte d'Ivoire \\ ${ }^{4}$ Center for Atomic, Molecular Physics and Quantum Optics (CEPAMOQ), University of Douala, Douala, Cameroon \\ Email: ^briguiolkale@gmail.com
}

How to cite this paper: Brigui, O.J.-C., Dali, T.P.A., Djagouri, K., Gogon, B.D.L.H., Penabei, S., Koua, A.A. and Monnehan, G.A. (2022) Measurement of Natural Radioactivity in Lagoon Sands Used in Construction in the District of Abidjan, Côte d'Ivoire. World Journal of Nuclear Science and Technology, 12, 43-54.

https://doi.org/10.4236/wjnst.2022.121005

Received: December 23, 2021

Accepted: January 25, 2022

Published: January 28, 2022

Copyright $\odot 2022$ by author(s) and Scientific Research Publishing Inc. This work is licensed under the Creative Commons Attribution International License (CC BY 4.0).

http://creativecommons.org/licenses/by/4.0/

\begin{abstract}
Sand is an important natural material for the construction of houses, work buildings and other public spaces. This work, which is one of the first contributions to the environmental quality of construction materials, concerns the measurement of natural radioactivity in the lagoon sands collected in the district of Abidjan. Nineteen (19) samples of these sands are analyzed by gamma-ray spectrometry equipped with HPGe detector. The mean values obtained for ${ }^{226} \mathrm{Ra},{ }^{232} \mathrm{Th}$ and ${ }^{40} \mathrm{~K}$ are respectively $7.76 \pm 1.84 \mathrm{~Bq} \cdot \mathrm{kg}^{-1}, 5.21 \pm 1.36$ $\mathrm{Bq} \cdot \mathrm{kg}^{-1}$, and $217.31 \pm 5.03 \mathrm{~Bq} \cdot \mathrm{kg}^{-1}$. The estimated average value of radium equivalent (Raeq) is $31.94 \mathrm{~Bq} \cdot \mathrm{kg}^{-1}$. The results show that the average values obtained are far lower than the global limits of 35,30 , and $400 \mathrm{~Bq} \cdot \mathrm{kg}^{-1}$ for the concentrations of ${ }^{226} \mathrm{Ra},{ }^{232} \mathrm{Th}$ and ${ }^{40} \mathrm{~K}$, respectively, and $370 \mathrm{~Bq} \cdot \mathrm{kg}^{-1}$ for the equivalent radium established by the United Nations Scientific Committee on the Effects of Atomic Radiation (UNSCEAR). Therefore, the use of the analyzed lagoon sand samples in the different construction sectors should not cause serious radiological effects on the populations living in the District of Abidjan. Our results provide new data on building materials radioactivity in Côte d'Ivoire and all over the World. They can also be used as a reference for future work.
\end{abstract}

\section{Keywords}

Radionuclide Concentration, Gamma-Ray Spectrometry, Radium Equivalent Activity, Lagoon Sand, Abidjan 


\section{Introduction}

Exposure to ionizing radiation from sources of radioactivity in the environment represents one of the major health risks for human beings. The most important natural radionuclides which could cause radiation protection problems are uranium $\left({ }^{238} \mathrm{U}\right.$ and $\left.{ }^{235} \mathrm{U}\right)$, thorium $\left({ }^{232} \mathrm{Th}\right)$, their decay products, and potassium $\left({ }^{40} \mathrm{~K}\right)$ [1]. Construction materials generally contain different amounts of radionuclides which depend both on the nature of the soil and on the geological position in a geographic area. Therefore, construction materials represent a permanent source of ionizing radiation because people spend more time (estimated at $80 \%$ indoors) in built environments (homes, workplaces and entertainment spaces) [2] In this context, great interest has been given to determining the levels of radioactivity in building materials in many countries [3]-[10]. In Côte d'Ivoire, the number of construction projects is in perpetual growth in recent years. This is the result of strong demographic growth. As a result, sand extraction from the lagoon has increased considerably, particularly in the District of Abidjan to supply the construction market. At present, knowledge of the radiological impacts related to construction materials is limited because little study has been dedicated to them compared to other environmental studies. In this context, the objective of this work is to assess the levels of natural radioactivity in the lagoon sand samples collected from the District of Abidjan.

\section{Materials and Methods}

\subsection{Study Area}

The District of Abidjan is located between latitudes $5^{\circ} 10^{\prime}$ and $5^{\circ} 38^{\prime}$ North and longitudes $3^{\circ} 45^{\prime}$ and $4^{\circ} 21^{\prime}$ West and occupies an area of $2119 \mathrm{~km}^{2}$. Its population density is estimated at 2221 inhabitants $/ \mathrm{km}^{2}$. According to the recent census, its population is estimated at 4,707,404 inhabitants, with a growth rate of $3.7 \%$ [11]. Geologically, the lithology of the study area consists of clayey sand, medium sands and coarse sands resting on a granite and schist base [12]. From a hydrological point of view, the district of Abidjan is covered by a dense hydrographic network made up of three main lagoons (parallel to the Atlantic Ocean and intersecting the coast) EBRIE AGHIEN and POKOU as well as many rivers (Figure 1). A large amount of sandy sediment has developed at the bottom of these lagoons which makes this region one of the most important sand production regions in Cote d'Ivoire.

\subsection{Materials}

\subsubsection{Sampling and Preparation Equipment}

The materials analyzed during this work are nineteen (19) samples of lagoon sand. The equipment used in the field for sample collection includes a Garmin (Etrex) brand GPS to determine geographic coordinates, shovels for manual collection and polythene sample bags. The laboratory equipment used for sample preparation consists of an electronic balance (METTLER TOLEDO brand, Model 


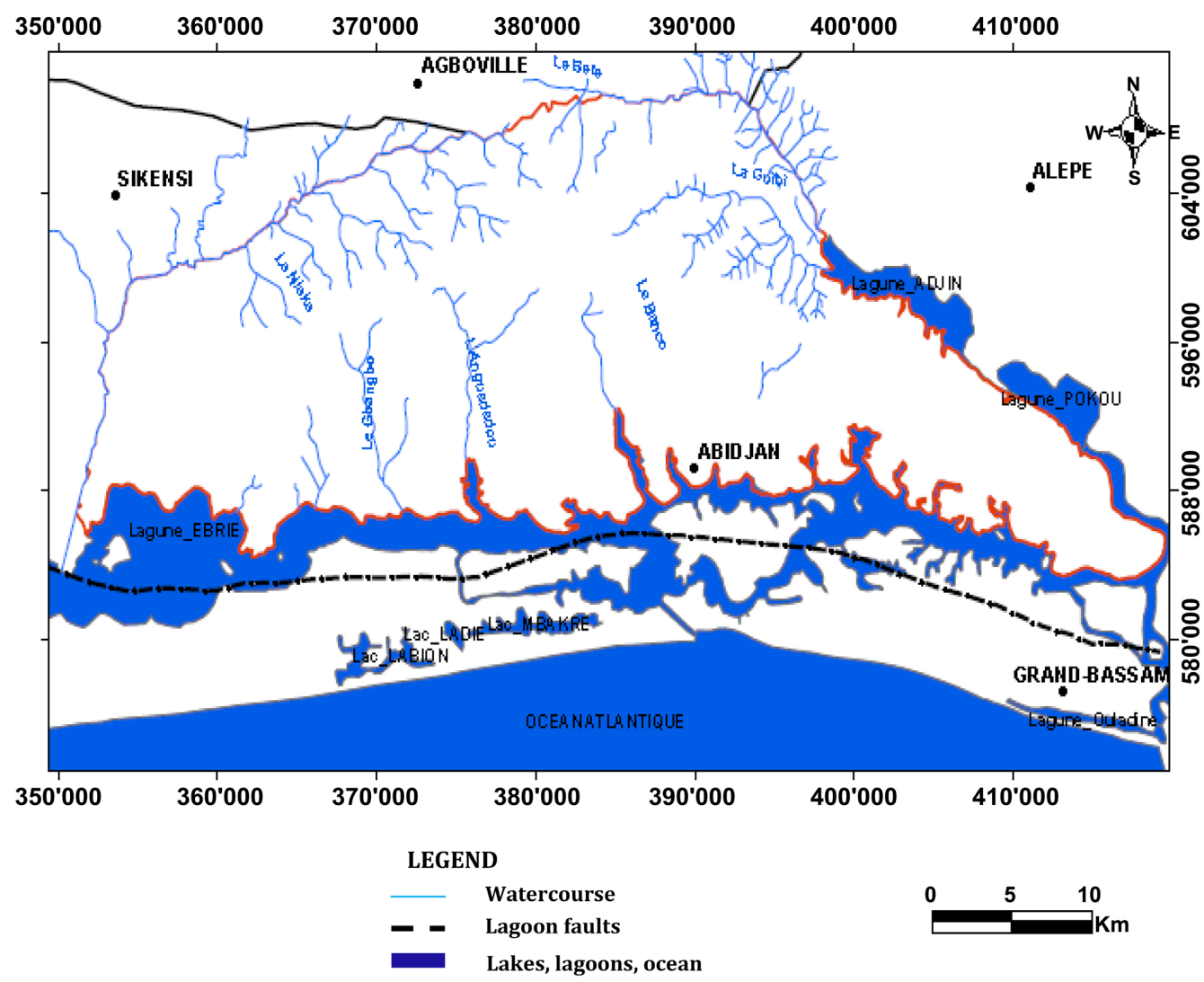

Figure 1. Map of the study area (District of Abidjan).

XP2001S, SNR) for different mass measurements of the samples. There are also Marinelli beakers (SG 500) for the conditioning of the samples, an oven to dry these samples, a ball mill, and a sieve of 2 millimeters mesh.

\subsubsection{Equipment Analysis}

The radioactivity of the sand samples is measured using the gamma-ray spectrometer installed at the laboratory of the Radiation Protection Institute (RPI) of the Ghana Atomic Energy Commission (GAEC). The measurement chain includes the measurement chamber, a liquid nitrogen cooling system (77 K), a High Purity Germanium (HPGe) coaxial detector model GX 4020-7500 SL (Canberra) with a resolution of $2 \mathrm{keV}$ at $1332 \mathrm{keV}\left({ }^{60} \mathrm{Co}\right)$. There is also a high voltage power supply (4000 V) necessary for the collection of the electric charges deposited in the detector. A cylindrical lead shielding $10 \mathrm{~cm}$ thick makes the contributions of ambient radiation reduction possible. Moreover, there is a multichannel analyzer (MCA) connected to a computer with an acquisition and processing software (GENIE 2000, Canberra). For the calibration, we used standard multi sources composed of ${ }^{241} \mathrm{Am},{ }^{109} \mathrm{Cd},{ }^{139} \mathrm{Ce},{ }^{113} \mathrm{Sn},{ }^{137} \mathrm{Cs},{ }^{57} \mathrm{Co},{ }^{60} \mathrm{Co}$, and ${ }^{88} \mathrm{Y}$.

\subsection{Methods}

\subsubsection{Samples Collection}

The nineteen sand samples are collected from the main suppliers and at the con- 
struction sites. Each sample is a combination of five (5) incremental samples taken at random from five points in the sand stock from a depth of approximately $15 \mathrm{~cm}$. Two (2) kilograms of each sample is collected and packaged in contamination-free polyethylene bags, adequately labeled in situ to facilitate their exact identification in the preparation laboratory.

\subsubsection{Preparation Methods}

In laboratory, all samples are dried at $105^{\circ} \mathrm{C}$ in an oven until all moisture has been removed. A constant dry weight of the samples is obtained after 24 hours. The samples are then crushed and sieved (at $2 \mathrm{~mm}$ ) in order to get rid of the unwanted fractions. After their reduction to a homogeneous powder, the samples are conditioned in Marinelli type geometry (SG 500), sealed against radon for 30 days before the measurements in order to allow a secular equilibrium. This equilibrium corresponds to at least seven half-lives of ${ }^{222} \mathrm{Rn}(3.81 \mathrm{~d})$ between the radionuclides ${ }^{226} \mathrm{Ra}$ and ${ }^{232} \mathrm{Th}$ and their respective descendants [13].

\subsubsection{Radioactivity Measurement}

The radioactivity measurement of the samples was carried out at the laboratory of GAEC. One (1) kilogram dry mass sand samples are measured for 10 hours using a Gamma-ray spectrometer. During the measurement, the HPGe detector mounted on the cryostat is cooled with liquid nitrogen $(77 \mathrm{~K})$ in order to decrease the resistivity of the material and reduce the thermal background noise. The detector is also surrounded by a cylindrical lead castle of $10 \mathrm{~cm}$ thick to attenuate the background noise in the measured spectrum due to natural ambient radioactivity. Spectra analysis are performed using Genie 2000 (Canberra) software. The spectrum of each sample gives the number of counts recorded per second as a function of the energy of the gamma rays emitted by the radionuclides. Background measurements of the laboratory are also carried out in order to obtain net counts for each sample. Thus, an empty Marinelli beaker is measured to find the background noise generated by the ambient natural radioactivity. This background noise is then subtracted from the activities of each radionuclide in the measured samples.

The energy and the calibration efficiency of the detector are determined using a standard multi-source with energies between 60 and $2000 \mathrm{keV}$. This makes it possible to take into account the desired radionuclides and reduce the counting losses linked to the coincidence summing and self-absorption effects of gamma rays. The energy and calibration efficiency of the detector, respectively, are used to identify the radionuclides detected in the samples. Thus, we can determine their concentrations [14].

\subsubsection{Activity Concentration}

The activity concentrations of radionuclides in the sand samples are calculated using the equation below.

$$
C=\frac{N_{n e t}}{\varepsilon \cdot P \cdot t_{c} \cdot m_{s}} \quad[15]
$$


where: $N_{n e t}, \varepsilon, t_{c}(\mathrm{~s}), m_{s}(\mathrm{~kg}), p(\%)$ are, respectively, the number of net counts below the photoelectric peak for each sample, the detection efficiency for specific gamma energy, the count time, dry mass of the sample and probability of detection.

The ${ }^{40} \mathrm{~K}$ radioactivity is measured directly from the Gamma-ray emitted at $1460.8 \mathrm{keV}$ (10.7\%). The radioactivity of ${ }^{226} \mathrm{Ra}$ and ${ }^{232} \mathrm{Th}$ is measured from their descendants in secular equilibrium by making the average of their respective activities. Thus, the gamma rays of ${ }^{214} \mathrm{~Pb}$ at 295.2 (19.3\%) keV and 351.9 (35.8\%) $\mathrm{keV}$, and the gamma rays of ${ }^{214} \mathrm{Bi}$ at 609.3 (46.1\%) keV and 1764.5 (15.1\%) keV are used for the measurement of ${ }^{226} \mathrm{Ra}$. The ${ }^{232} \mathrm{Th}$ radioactivity is measured using the $911.2(26.6 \%) \mathrm{keV}$ line of ${ }^{228} \mathrm{Ac}$ and the $583.2(30.5 \%) \mathrm{keV}$ line of ${ }^{208} \mathrm{Tl}$.

The minimum detectable activity (MDA) of the measurement system is calculated using the following equation:

$$
\mathrm{MDA}=\frac{\sigma \sqrt{B}}{\varepsilon_{\gamma} \cdot P_{\gamma} \cdot t_{c} \cdot m_{e}} \quad[16]
$$

where: $\sigma, B, \varepsilon_{\gamma}, P_{\gamma}, t_{c}(\mathrm{~s}), m_{s}(\mathrm{~kg})$ are, respectively, the statistical coverage factor (equal to 1.645 at the $95 \%$ confidence level), the background noise, the efficiency of the detector (HPGe), the probability of emission of gamma rays, the counting time and the dry mass of the sample.

The calculated MDAs are $0.12 \mathrm{~Bq} \cdot \mathrm{kg}^{-1}$ for ${ }^{229} \mathrm{Ra}, 0.11 \mathrm{~Bq} \cdot \mathrm{kg}^{-1}$ for ${ }^{232} \mathrm{Th}$, and $0.15 \mathrm{~Bq} \cdot \mathrm{kg}^{-1}$ for ${ }^{40} \mathrm{~K}$.

\subsubsection{Radium Equivalent Activity ( $\left.\mathrm{Ra}_{\mathrm{eq}}\right)$}

The distribution of radionuclides ${ }^{226} \mathrm{Ra},{ }^{232} \mathrm{Th}$ and ${ }^{40} \mathrm{~K}$ in terrestrial materials is not uniform. The risk induced by the radioactivity existing in a building material is evaluated by different models among them the equivalent radium $\left(\mathrm{Ra}_{\mathrm{eq}}\right) \cdot \mathrm{Ra}_{\mathrm{eq}}$ is defined as the weighted sum of the activities of ${ }^{226} \mathrm{Ra}$, ${ }^{232} \mathrm{Th}$, and ${ }^{40} \mathrm{~K}$, according to Equation (3).

$$
\mathrm{Ra}_{\mathrm{eq}}=\mathrm{C}_{\mathrm{Ra}}+1.43 \mathrm{C}_{\mathrm{Th}}+0.077 \mathrm{C}_{\mathrm{K}} \quad[17] .
$$

where: $\mathrm{Ra}_{\mathrm{eq}}\left(\mathrm{Bq} \cdot \mathrm{kg}^{-1}\right)$ represents the equivalent radium number; $\mathrm{C}_{\mathrm{Ra}}, \mathrm{C}_{\mathrm{Th}}$ and $\mathrm{C}_{\mathrm{K}}$ activity concentrations $\left(\mathrm{Bq} \cdot \mathrm{kg}^{-1}\right)$ of ${ }^{226} \mathrm{Ra},{ }^{232} \mathrm{Th}$, and ${ }^{40} \mathrm{~K}$, respectively.

The constants 1, 1.43 and 0.077 are risk conversion coefficients established on the basis that $370 \mathrm{~Bq} \cdot \mathrm{kg}^{-1}$ of ${ }^{226} \mathrm{Ra}, 259 \mathrm{~Bq} \cdot \mathrm{kg}^{-1}$ of ${ }^{232} \mathrm{Th}$, and $4810 \mathrm{~Bq} \cdot \mathrm{kg}^{-1}$ of ${ }^{40} \mathrm{~K}$, respectively, produce the same flow gamma dose. The maximum value of $\mathrm{Ra}_{\mathrm{eq}}$ recommended is $370 \mathrm{~Bq} \cdot \mathrm{kg}^{-1}$ for safer use of the material [2].

\section{Results and Discussions}

\subsection{Activity Concentration}

The activity concentration results acquired for the nineteen (19) sand samples using Equation (1) are shown in Table 1 and in graphical forms from Figures 1-6. Descriptive statistics (minimum, maximum, average) are also shown.

According to Table $1,{ }^{232} \mathrm{Th}$ concentrations generally vary and range from 
Table 1. Activity concentrations of ${ }^{226} \mathrm{Ra},{ }^{232} \mathrm{Th}$ and ${ }^{40} \mathrm{~K}$ and the radium equivalent activity $\left(\mathrm{Ra}_{\mathrm{eq}}\right)$.

\begin{tabular}{|c|c|c|c|c|c|c|c|c|c|c|c|}
\hline \multirow{3}{*}{$\begin{array}{c}\text { Samples } \\
\text { SAB-1 }\end{array}$} & \multirow{3}{*}{$\begin{array}{c}\text { Sites } \\
\text { Koumassi }\end{array}$} & \multicolumn{9}{|c|}{ Activity concentrations $\left(\mathrm{Bq} \cdot \mathrm{kg}^{-1}\right)$} & \multirow{3}{*}{$\begin{array}{c}\text { Radium equivalent } \\
\qquad \mathrm{Ra}_{\mathrm{eq}}\left(\mathrm{Bq} \cdot \mathrm{kg}^{-1}\right) \\
28.61\end{array}$} \\
\hline & & \multicolumn{3}{|c|}{${ }^{226} \mathrm{Ra}$} & \multicolumn{3}{|c|}{${ }^{232} \mathrm{Th}$} & \multicolumn{3}{|c|}{${ }^{40} \mathrm{~K}$} & \\
\hline & & 4.48 & \pm & 0.65 & 6.67 & \pm & 2.49 & 189.51 & \pm & 2.47 & \\
\hline SAB-2 & Portbouet & 1.9 & \pm & 0.66 & 3.74 & \pm & 0.18 & 160.74 & \pm & 1.05 & 19.63 \\
\hline SAB-3 & Portbouet & 3.15 & \pm & 0.05 & 5.38 & \pm & 0.23 & 170.23 & \pm & 3.29 & 23.95 \\
\hline SAB- 4 & Marcory & 3.35 & \pm & 0.28 & 5.84 & \pm & 1.91 & 251.24 & \pm & 7.32 & 31.05 \\
\hline SAB-5 & Yopougon & 15.3 & \pm & 0.83 & 4.41 & \pm & 0.16 & 225.64 & \pm & 4.15 & 38.98 \\
\hline SAB-6 & Yopougon & 12.77 & \pm & 3.75 & 4.4 & \pm & 1.98 & 244.62 & \pm & 4.2 & 37.90 \\
\hline SAB-7 & Mpouto & 2.43 & \pm & 0.83 & 4.64 & \pm & 0.98 & 170.09 & \pm & 4.1 & 22.16 \\
\hline SAB-8 & Abatta & 8.45 & \pm & 1.85 & 7.62 & \pm & 0.38 & 218.2 & \pm & 3.79 & 36.15 \\
\hline SAB-9 & Abatta & 9.78 & \pm & 2.97 & 7.05 & \pm & 2.93 & 258.41 & \pm & 5.93 & 39.76 \\
\hline SAB-10 & Bingerville & 8.37 & \pm & 2.93 & 4.51 & \pm & 0.93 & 231.5 & \pm & 7.93 & 32.64 \\
\hline SAB-11 & Bingerville & 10.45 & \pm & 2.87 & 6.16 & \pm & 0.76 & 245.63 & \pm & 6.12 & 38.17 \\
\hline SAB-12 & Bingerville & 11.12 & \pm & 1.79 & 8.2 & \pm & 0.27 & 255.16 & \pm & 5.78 & 42.49 \\
\hline SAB-13 & Songon & 5.98 & \pm & 1.94 & 3.47 & \pm & 0.99 & 167.61 & \pm & 5.94 & 23.85 \\
\hline SAB-14 & Songon & 8.76 & \pm & 2.95 & 4.91 & \pm & 1.53 & 296.91 & \pm & 6.93 & 38.64 \\
\hline SAB-15 & Songon & 6.27 & \pm & 1.85 & 5.13 & \pm & 2.54 & 190.44 & \pm & 4.85 & 28.27 \\
\hline SAB-16 & Songon & 8.78 & \pm & 2.43 & 4.73 & \pm & 1.97 & 186.92 & \pm & 5.63 & 29.94 \\
\hline SAB-17 & Grand-Bassam & 10.89 & \pm & 2.65 & 4.95 & \pm & 1.61 & 248.67 & \pm & 6.4 & 37.12 \\
\hline SAB-18 & Grand-Bassam & 7.23 & \pm & 1.22 & 2.73 & \pm & 0.87 & 208.18 & \pm & 4.9 & 27.16 \\
\hline SAB-19 & Grand-Bassam & 7.99 & \pm & 2.42 & 4.45 & \pm & 3.15 & 209.11 & \pm & 4.83 & 30.45 \\
\hline Mean Value & & 7.76 & \pm & 1.84 & 5.21 & \pm & 1.36 & 217.31 & \pm & 5.03 & 31.94 \\
\hline [Min - Max] & & \multicolumn{3}{|c|}{$[1.9-15.3]$} & \multicolumn{3}{|c|}{$[2.73-8.2]$} & \multicolumn{3}{|c|}{ [160.74 - 296.91] } & [19.63 - 42.49] \\
\hline
\end{tabular}

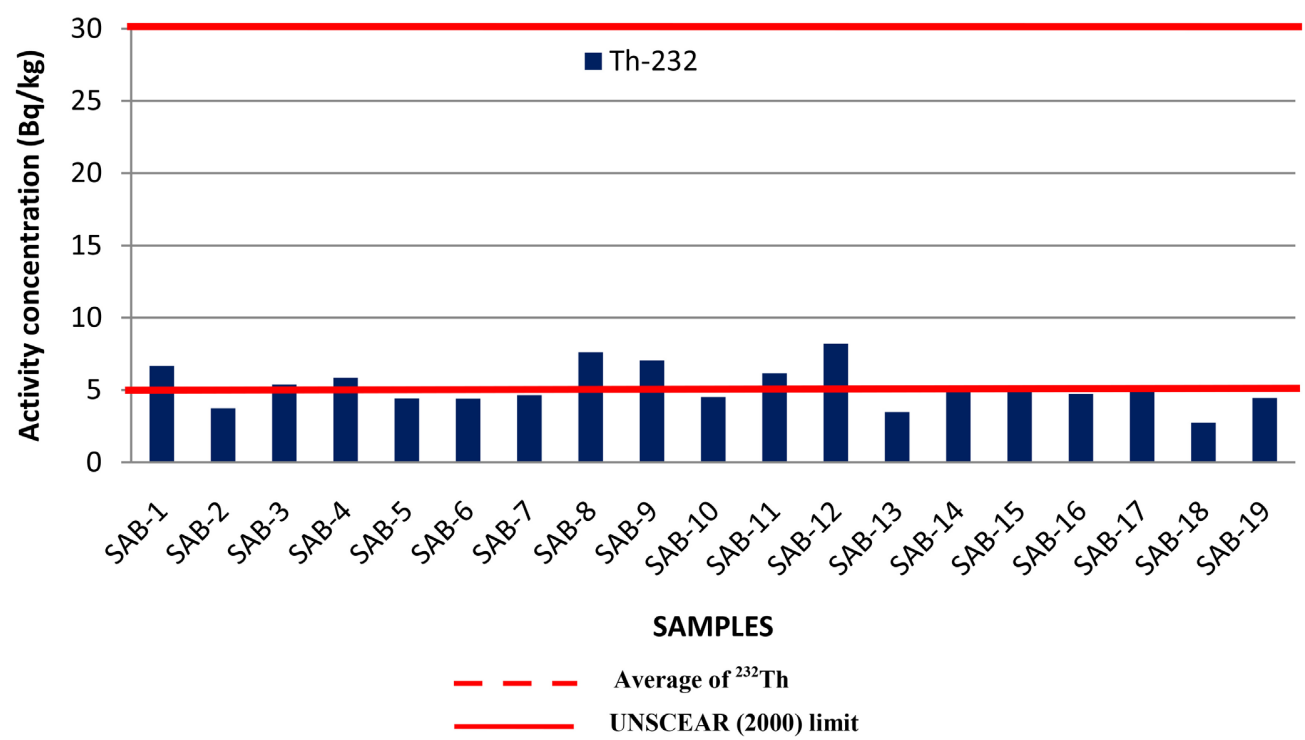

Figure 2. Variation in activity concentration of ${ }^{232} \mathrm{Th}$ in the sand samples. 


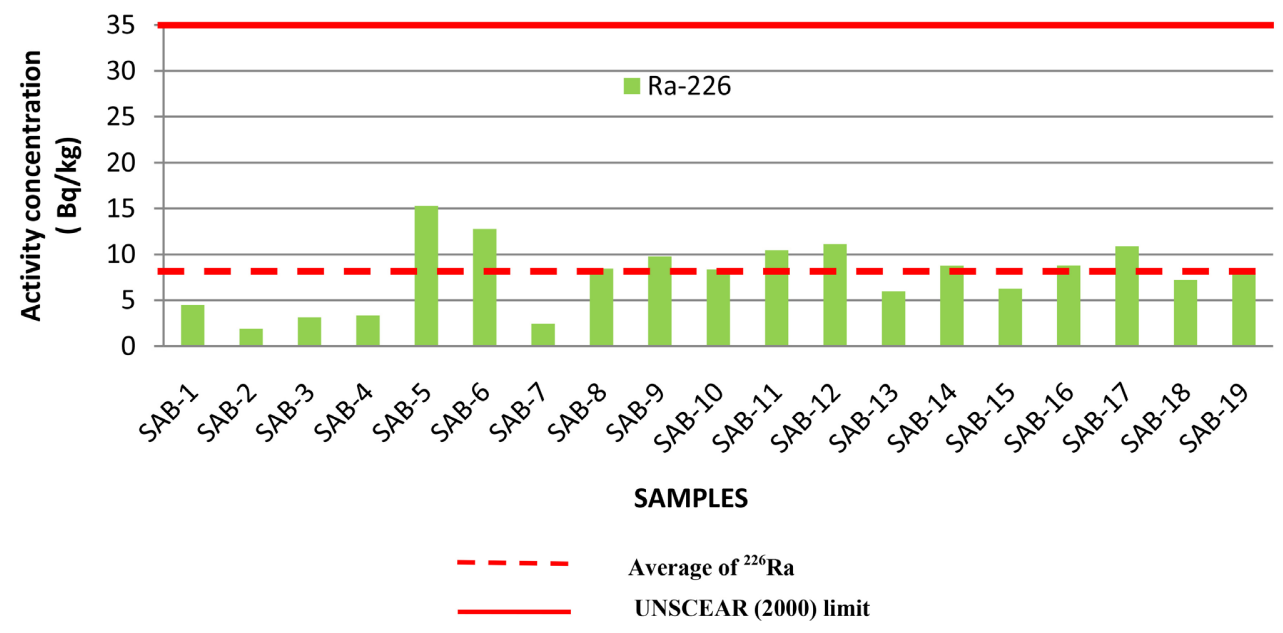

Figure 3. Variation in activity concentration of ${ }^{226} \mathrm{Ra}$ in the sand samples.

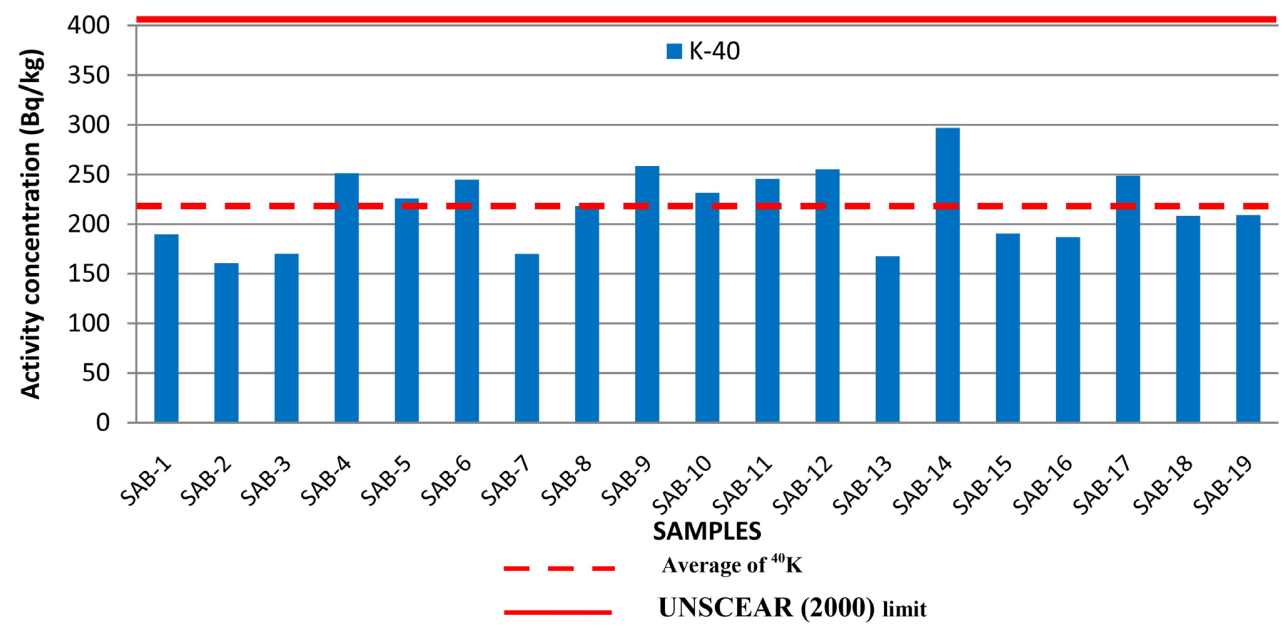

Figure 4. Variation in activity concentration of ${ }^{40} \mathrm{~K}$ in the sand samples.

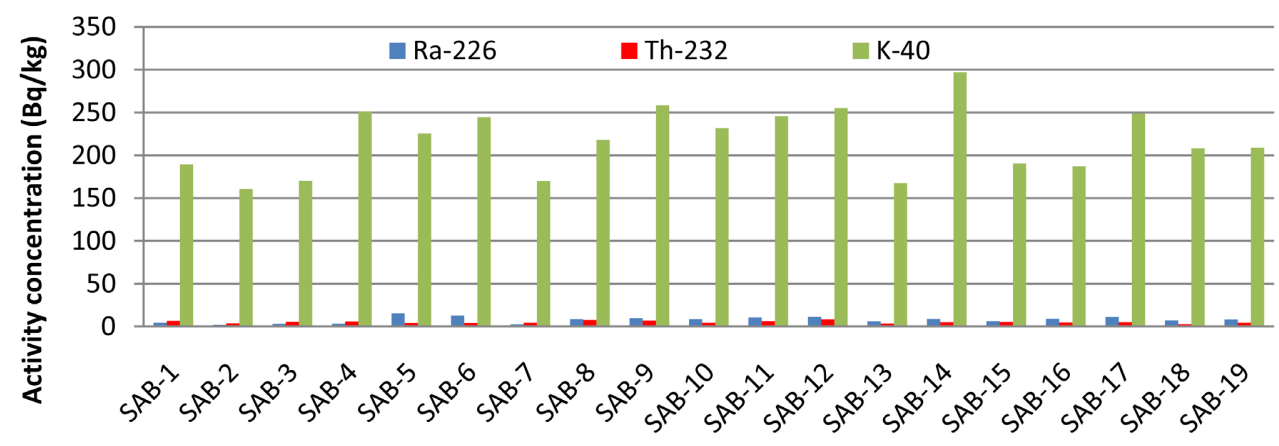

SAMPLES

Figure 5. Comparison of the activity concentration of ${ }^{226} \mathrm{Ra},{ }^{232} \mathrm{Th}$, and ${ }^{40} \mathrm{~K}$, in sand samples.

$(2.73 \pm 0.16) \mathrm{Bq} \cdot \mathrm{kg}^{-1}$ in the $\mathrm{SAB}-18$ sample to $(8.2 \pm 3.15) \mathrm{Bq} \cdot \mathrm{kg}^{-1}$ in sample SAB-12. These concentrations obtained are far above the limit of detection $(0.11$ $\left.\mathrm{Bq} \cdot \mathrm{kg}^{-1}\right)$. The differences observed between the concentrations are probably dependent on the geological origin of the samples. In addition, by comparison with 


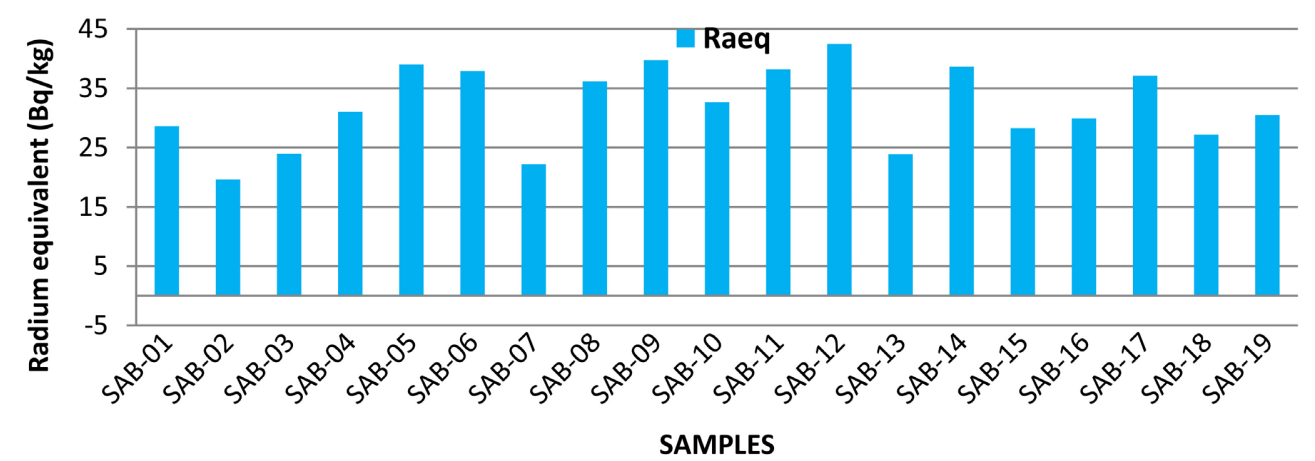

Figure 6. Variation of radium equivalent $\left(\mathrm{Ra}_{\mathrm{eq}}\right)$ in sand samples.

the world average, we can notice that the average concentration of ${ }^{232} \mathrm{Th}$ found $(5.21 \pm 1.36) \mathrm{Bq} \cdot \mathrm{kg}^{-1}$ is lower (6 times) than the UNSCEAR limit (2000) of 30 $\mathrm{Bq} \cdot \mathrm{kg}^{-1}$ [2] shown in Figure 2. Comparing with the mean values measured in other countries (Table 2), it can be seen that the mean value of ${ }^{232} \mathrm{Th}$ in this work is similar to $5 \mathrm{~Bq} \cdot \mathrm{kg}^{-1}$ measured in Kenya but lower than the value of 3.2 $\mathrm{Bq} \cdot \mathrm{kg}^{-1}$ found in Egypt. However, the value of $119.42 \mathrm{~Bq} \cdot \mathrm{kg}^{-1}$ measured in India is more than 20 times higher than in our work. The activity concentrations of ${ }^{226} \mathrm{Ra}$ obtained are slightly higher than those of ${ }^{232} \mathrm{Th}$ (Figure 5). From the results of the samples shown in Figure 3, one can notice that the concentrations of ${ }^{226} \mathrm{Ra}$ vary in all measurements. This variation is from $(1.9 \pm 0.05) \mathrm{Bq} \cdot \mathrm{kg}^{-1}$ in the SAB-2 sample to $(15.3 \pm 3.75) \mathrm{Bq} \cdot \mathrm{kg}^{-1}$ in the SAB-5 sample, and none is below the detection limit. The differences observed between the concentrations of ${ }^{226} \mathrm{Ra}$ are probably dependent on the geological origin of the samples. In addition, according to Figure 3, we notice that the average value of the concentration of ${ }^{226} \mathrm{Ra}\left(7.76 \mathrm{~Bq} \cdot \mathrm{kg}^{-1}\right)$ is lower (5 times) than the standard imposed by UNSCEAR (2000) which is estimated by $35 \mathrm{~Bq} \cdot \mathrm{kg}^{-1}$ [2]. The comparison of the values with those of other studies made on sand (Table 2) allows noticing that the average value obtained in this work is lower than $37 \mathrm{~Bq} \cdot \mathrm{kg}^{-1}$ measured in the USA and 44 $\mathrm{Bq} \cdot \mathrm{kg}^{-1}$ recorded in Turkey but slightly higher than the value of $3.7 \mathrm{~Bq} \cdot \mathrm{kg}^{-1} \mathrm{ob}-$ tained in Australia. According to Figure 5, the concentrations of ${ }^{40} \mathrm{~K}$ in the samples are the highest. This could be explained by the fact that originally the ${ }^{40} \mathrm{~K}$ radionuclide is the most abundant in the earth's crust [18]. As for the ${ }^{226} \mathrm{Ra}$ and the ${ }^{232} \mathrm{Th}$, the values of ${ }^{40} \mathrm{~K}$ generally vary between $(160.74 \pm 1.05) \mathrm{Bq} \cdot \mathrm{kg}^{-1}$ in the sample SAB-2 to $(296.91 \pm 7.93) \mathrm{Bq} \cdot \mathrm{kg}^{-1}$ in SAB-14 while fluctuating according to the sampling points. Figure 4 shows the variation of ${ }^{40} \mathrm{~K}$ concentration in sand samples. As can be seen, all the levels shown in this graph are well above the detection limit of $0.15 \mathrm{~Bq} \cdot \mathrm{kg}^{-1}$. In addition, as can also be seen from the data in Figure 4 some values are different from point to point while others are similar. These deviations could indicate a difference in the geological origin of these samples. Moreover, the comparison at the world level shows that the average value $217.31 \mathrm{~Bq} \cdot \mathrm{kg}^{-1}$ obtained with regard to the (19) samples studied is twice above the limit of UNSCEAR (2000) quantified at $400 \mathrm{~Bq} \cdot \mathrm{kg}^{-1}$ [2]. Moreover, by comparing the average value with those of some other countries cited in Table 2 
Table 2. Mean concentration values of ${ }^{226} \mathrm{Ra},{ }^{232} \mathrm{Th}$, and ${ }^{40} \mathrm{~K}$ obtained in this study and in some other countries.

\begin{tabular}{ccccc}
\hline \multirow{2}{*}{ Countries } & \multicolumn{2}{c}{ activity concentrations $\left(\mathrm{Bq} \cdot \mathrm{kg}^{-1}\right)$} & Références \\
\cline { 2 - 4 } & ${ }^{226} \mathrm{Ra}$ & ${ }^{232} \mathrm{Th}$ & ${ }^{40} \mathrm{~K}$ & \\
\hline USA & 37 & 33.3 & 18.5 & {$[19]$} \\
Brazil & 10.2 & 12.6 & 51 & {$[20]$} \\
Jordan & 3.7 & 40.7 & 44.7 & {$[21]$} \\
Turkey & 44 & 26 & 441 & {$[6]$} \\
Netherlands & 8 & 11 & 200 & {$[22]$} \\
India & 4.57 & 119.42 & 388.78 & {$[8]$} \\
Egypt & 9.2 & 3.3 & 47.3 & {$[7]$} \\
Bangladesh & 14.2 & 25 & 158.4 & {$[23]$} \\
Kenya & 11 & 5 & 802 & {$[24]$} \\
Côte d'Ivoire & $7.76 \pm 1.84$ & $5.2 \pm 1.36$ & $217.31 \pm 5.03$ & Present work \\
\hline
\end{tabular}

for sand, we see that the value of ${ }^{40} \mathrm{~K}\left(217.31 \mathrm{~Bq} \cdot \mathrm{kg}^{-1}\right)$ found in this work is much lower than the values of $388.78 \mathrm{~Bq} \cdot \mathrm{kg}^{-1}, 441 \mathrm{~Bq} \cdot \mathrm{kg}^{-1}$ and $802 \mathrm{~Bq} \cdot \mathrm{kg}^{-1}$ measured respectively in India, Turkey and Kenya. However, we note that for the value of 18.5 Bq. $\mathrm{kg}^{-1}$ and $44.7 \mathrm{~Bq} \cdot \mathrm{kg}^{-1}$ recorded in the USA and Australia, the measured average value of this is higher. The differences observed between the concentrations of ${ }^{226} \mathrm{Ra},{ }^{232} \mathrm{Th}$, and ${ }^{40} \mathrm{~K}$ resulting from this study compared to those of the countries considered are probably related to the origin of the samples. They could be linked to the inhomogeneous distribution of natural radioactivity in soils and rocks in different regions of the world in relation to the geological and geochemical conditions found locally [2].

\subsection{Radium Equivalent Activity ( $R a_{\text {eq }}$ )}

To demonstrate the relationship between all these measured concentrations and their radiological impact, the radium equivalent activity $\left(\mathrm{Ra}_{\mathrm{eq}}\right)$ is estimated using Equation (3). According to Table 1, the $\mathrm{Ra}_{\mathrm{eq}}$ values vary from 19.63 to 42.49 $\mathrm{Bq} \cdot \mathrm{kg}^{-1}$ with average value of $31.94 \mathrm{~Bq} \cdot \mathrm{kg}^{-1}$. The highest value is measured in the SAB-2 sample while the lowest is recorded in the SAB-12 sample. Figure 6 represents the variation of $\mathrm{Ra}_{\mathrm{eq}}$ in samples. It reveals marked differences in radium equivalent between some samples. These differences are linked to the differences observed in the activity concentrations of radionuclides according to the sampling points. Moreover, all the values of $\left(\mathrm{Ra}_{\mathrm{eq}}\right)$ obtained in this study are lower than the average value recommended by UNSCEAR [2] which is 370 $\mathrm{Bq} \cdot \mathrm{kg}^{-1}$. Therefore, the use of the analyzed sands in the construction works could not cause significant radiological risks in the short term.

\section{Conclusion}

Gamma-ray spectrometry is used to measure the activity concentrations of ${ }^{226} \mathrm{Ra}$, 
${ }^{232} \mathrm{Th}$ and ${ }^{40} \mathrm{~K}$ present in nineteen samples of lagoon sand used in different constructions in the district of Abidjan (Côte d'Ivoire). The average activity concentrations of the radionuclides provided by this study are $7.76 \pm 1.84 \mathrm{~Bq} \cdot \mathrm{kg}^{-1}, 5.21$ $\pm 1.36 \mathrm{~Bq} \cdot \mathrm{kg}^{-1}, 217.31 \pm 5.03 \mathrm{~Bq} \cdot \mathrm{kg}^{-1}$, respectively. The estimated average radium equivalent $\left(\mathrm{Ra}_{\mathrm{eq}}\right)$ value is $31.94 \mathrm{~Bq} \cdot \mathrm{kg}^{-1}$. The average values of the estimated activity and radium equivalent concentrations were compared to the international average values. The results obtained show that the estimated average values are below the world limits of $35 \mathrm{~Bq} \cdot \mathrm{kg}^{-1} 30 \mathrm{~Bq} \cdot \mathrm{kg}^{-1}$ and $400 \mathrm{~Bq} \cdot \mathrm{kg}^{-1}$ for the concentrations of ${ }^{226} \mathrm{Ra},{ }^{232} \mathrm{Th}$ and ${ }^{40} \mathrm{~K}$, respectively, and of $370 \mathrm{~Bq} \cdot \mathrm{kg}^{-1}$ for the radium equivalent activity. Therefore, the short-term radiological hazards of the lagoon sand samples used in constructions in the District of Abidjan are considered negligible. However, the radiological risks due to cumulative exposure dose should be assessed considering long-term exposure. In perspective, future studies will be oriented towards the determination of the long-term carcinogenic effects and the contribution of these sands to indoor radon.

\section{Acknowledgements}

The authors thank the Radiation Protection Institute (RPI) of the Ghana Atomic Energy Commission (GAEC) for the use of their facilities.

\section{Conflicts of Interest}

The authors declare no conflicts of interest regarding the publication of this paper.

\section{References}

[1] United Nations Scientific Committee on the Effects of Atomic Radiation (UNSCEAR) (1993) Sources and Effects of Ionizing Radiation. United Nations Publication, New York.

[2] UNSCEAR (2000) Sources and Effects of Ionizing Radiation. Report to General Assembly, with Scientific Annexes. United Nations, New York.

[3] Ali, K.K. (2012) Radioactivity in Building Material in Iraq. Radiation Protection Dosimetry, 148, 372-379. https://doi.org/10.1093/rpd/ncr033

[4] Al-Haydari, A. (2011) Determination of Specific Activity of ${ }^{226} \mathrm{Ra},{ }^{232} \mathrm{Th}$ and ${ }^{40} \mathrm{~K}$ for Assessment of Environmental Hazards of Radiation from Building Rock Samples Used in Yemen. Radiation Protection Dosimetry, 148, 329-336. https://doi.org/10.1093/rpd/ncr031

[5] Bavarnegin, E., Moghaddam, M.V. and Fathabadi, N. (2013) Natural Radionuclide and Radiological Assessment of Building Materials in High Background Radiation Areas of Ramsar, Iran. Journal of Medical Physics, 38, 93-97. https://doi.org/10.4103/0971-6203.111325

[6] Cevic, U., Damla, N., Kobya, A.I., Celik, C. and Van, A. (2009) Assessment of Natural Radioactivity of Sand Used in Turkey. Journal of Radiation Protection, 29, 61-74. https://doi.org/10.1088/0952-4746/29/1/004

[7] Sharaf, M., et al. (1999) Natural Radioactivity and Radon Exhalation Rates in Building Materials Used in Egypt. Radiation Measurements, 31, 491-495. 
https://doi.org/10.1016/S1350-4487(99)00206-1

[8] Raghul, Y., Chandrasekaran, A., Selvapandiya, M., Harikrishnan, N. and Ravisankar, R. (2017) Natural Radioactivity Measurement and Radiological Hazards of Sand Samples Used as Building Material in Tiruvannamalai District, Tamilnadu, India.

[9] Li, J., Hu, B., Zhao, J., Bai, F., Dou, Y., Wang, L., Zou, L. and Ding, X. (2017) Evaluation of Natural Radioactivity in Marine Sand Deposits from Offshore China. Open Journal of Marine Science, 7, 357-378. https://doi.org/10.4236/ojms.2017.73026

[10] Khatun, M., Ferdous, J. and Haque, M. (2018) Natural Radioactivity Measurement and Assessment of Radiological Hazards in Some Building Materials Used in Bangladesh. Journal of Environmental Protection, 9, 1034-1048. https://doi.org/10.4236/jep.2018.910064

[11] RGPH (2014) Recensement Général de la Population et de l'Habitat (RGPH) en Côte d'Ivoire.

[12] Kouassi, K.A., Kouassi, W.F., Goula Bi, T.A., Kouame, K.I., Dibi, B. and Savane, I. (2010) Conceptual Model of Ivorian Sedimentary Costal Basin: Case of Abidjan Continental Terminal Aquifer. European Journal of Scientific Research, 44, 400-419.

[13] Prince, J.H. (1979) Comments on Equilibrium, Transition Equilibrium, and Secular Equilibrium in Serial Radioactive Decay. Journal of Nuclear Medicine, 20, 162-164.

[14] Mujahid, S.A., Rahim, A., Hussain, S. and Farooq, M. (2008) Measurement of Natural Radioactivity and Radon Exhalation Rates from Different Brands of Cement Used in Pakistan, Radiation Protection Dosimetry, 130, 206-212. https://doi.org/10.1093/rpd/ncm497

[15] Darko, E.O., Faanu, A., Razak, A., Emi-Reynolds, G., Yeboah, J., Oppon, O.C. and Akaho, E.H.K. (2008) Public Exposure Hazards Associated with Natural Radioactivity in Open Pit Mining in Ghana. Radiation Protection Dosimetry, 138, 45-51. https://doi.org/10.1093/rpd/ncp181

[16] Curie, L.A. (1968) Limits for Qualitative Detection and Quantitative Determination. Analytical Chemistry, 40, 586-593. https://doi.org/10.1021/ac60259a007

[17] Beretka, I. and Mathew, P.I. (1985) National Radioactivity of Australian Building Materials Waste and Products. Health Physics, 48, 87-95.

https://doi.org/10.1097/00004032-198501000-00007

[18] Omale, P.E., Okeniyi, S.O., Faruruwa, M.D. and Ngokat, A.B. (2014) Determination for Levels of Radionuclides of uranium, Thorium and Potassium in Water, Sediments and Algae Samples from Selected Coastal Areas of Lagos, Nigeria; Using Energy Dispersive X-Ray Fluorescence. Gjpacr, 2, 1-24.

[19] Ingersoll, G.J. (1983) A Survey of Radionuclide Contents and Radon Emanation rates in Building Materials in USA. Health Physics, 45, 363-368. https://doi.org/10.1097/00004032-198308000-00008

[20] Malanca, A. and Gaidolfi, L. (1996) Preliminary Radiological Survey in Some Towns of the Northeastern Brazilian Wilderness. Nucleus Journal, 33, 139-144.

[21] Ahmad, N., Matiullah, J. and Hussein, A.J.A. (1998) Natural Radioactivity in Jordanian Soil and Building Materials and the Associated Radiation Hazards. Journal of Environmental Radioactivity, 39, 9-22. https://doi.org/10.1016/S0265-931X(97)00046-5

[22] Ackers, J.G., den Boer, J.F., de Jong, P. and Wolfschrijin, N. (1985) Radioactivity and Radon Exhalation Rates of Building Materials in Netherland. Journal of Science of Total Environment, 45, 151-156. https://doi.org/10.1016/0048-9697(85)90215-3

[23] Chowdhury, M.L., Alain, M.N. and Ahmed, A.K.S., (1998) Concentration of Ra- 
dionuclides in Building and Ceramic Materials of Bangladesh and Evaluation of Radiation Hazard. Journal of Rationalistic Nuclear Chemistry, 231, 117-122.

https://doi.org/10.1007/BF02388016

[24] Mustapha, A.O., Pated, J.P. and Rathore, I.V.S. (1999) Assessment of Human Exposures to Natural Sources of Radiation in Kenya. Radiation Protection Dosimetry, 82, 285-292. https://doi.org/10.1093/oxfordjournals.rpd.a032637 